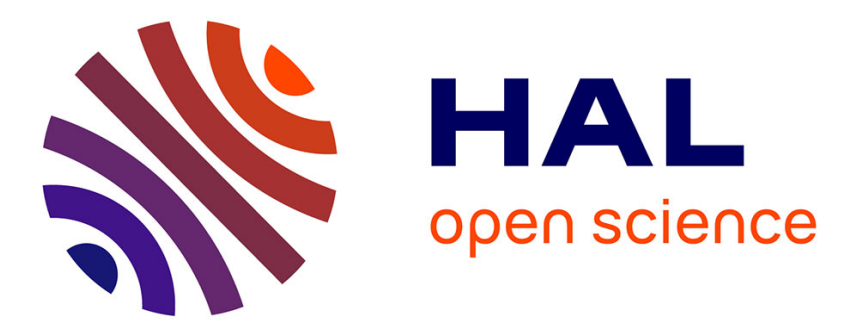

\title{
Microbiological analysis and assessment of biotechnological potential of lactic acid bacteria isolated from Tunisian flours
}

Insaf Nachi, Imene Fhoula, Imene Smida, Hadda-Imene Ouzari, Mnasser

Hassouna

\section{To cite this version:}

Insaf Nachi, Imene Fhoula, Imene Smida, Hadda-Imene Ouzari, Mnasser Hassouna. Microbiological analysis and assessment of biotechnological potential of lactic acid bacteria isolated from Tunisian flours. Annals of Microbiology, 2019, 69 (1), pp.29-40. 10.1007/s13213-018-1365-8 . hal-01944037

\section{HAL Id: hal-01944037 \\ https://hal-univ-rennes1.archives-ouvertes.fr/hal-01944037}

Submitted on 4 Dec 2018

HAL is a multi-disciplinary open access archive for the deposit and dissemination of scientific research documents, whether they are published or not. The documents may come from teaching and research institutions in France or abroad, or from public or private research centers.
L'archive ouverte pluridisciplinaire HAL, est destinée au dépôt et à la diffusion de documents scientifiques de niveau recherche, publiés ou non, émanant des établissements d'enseignement et de recherche français ou étrangers, des laboratoires publics ou privés. 
3

4 6

Insaf Nachi ${ }^{1}$, Imene Fhoula ${ }^{2}$, Imene Smida $^{3}$, Hadda-Imene Ouzari $^{2}$, and Mnasser Hassouna ${ }^{1}$

1, UR13AGR02 Unité de bio-conservation et valorisation des produits alimentaires. Université de Carthage, Ecole Supérieure des Industries Alimentaires, 58, avenue Alain Savary, 1003 Tunis, Tunisie.

2, LR03ES03 Laboratoire Microorganismes et Biomolecules Actives. Université de Tunis El Manar, Faculté des Science de Tunis, 2092, Campus Universitaire, Tunis, Tunisie.

3, INSERM U1241/ Nutrition Metabolism Cancer/CIMIAD, Université de Rennes, France.

*Corresponding author: ouzari.imene@gmail.com 


\section{Abstract}

The present work was carried out to identify lactic acid bacteria (LAB) from wheat flours and to evaluate their technological capabilities for potential incorporation in sourdough process. Six samples of baking wheat flours were collected from mills situated in different geographical regions of Tunisia and used for microbiological analysis of total mesophilic aerobic microorganisms, yeasts, moulds and LAB. A total of 45 autochthonous LAB were isolated and identified by genetic analysis of 16S-23S rRNA intergenic transcribed spacer ITS generated patterns ITS-PCR. One representative strain of each ITS-PCR pattern was subjected to partial sequencing of the 16S rRNA. Strains were identified as Weissella cibaria, Lactobacillus plantarum, Lactobacillus brevis, Pediococcus pentosaceus, Pediococcus pentoseus, Pediococcus acidilactici, Enterococcus faecium, Enterococcus casseliflavus and Enterococcus faecalis. Technological features including acidification, antimicrobial, amylolytic, proteolytic and antioxidant activities of six selected LAB strains were investigated for future in situ applications. Moreover, LAB were investigated for their ability to produce exopolysaccharides. All tested LAB showed good acidifying ability by decreasing significantly $(p<0.05)$ the $\mathrm{pH}$ of flour extract below 4.0 after $24 \mathrm{~h}$ and below 3.0 after 72 h. P. pentoseus and P. acidilactici presented fermentation quotient FQ (ratio of lactic and acetic acids) close to the optimal range. All flour LAB isolates, demonstrated extracellular proteolytic activity. W. cibaria S25 had the highest radical-scavenging activity with a rate of $25.57 \%$. L. plantarum S28 demonstrated the highest amylolytic activity (1386 U/mL) followed by P. acidilactici S16 (1086 $\mathrm{U} / \mathrm{mL})$. Although, L. plantarum S28 showed the highest production of exopolysaccharides (0.97 g/L). Moreover, different halo of inhibition were detected against E. coli, Staphylococcus aureus, Aspergillus niger and Penicillium expansum. This study revealed that autochthonous flour LAB exhibited interesting technological features and thus could be used in sourdough production.

Keywords: Baking flour, lactic acid bacteria, acidification, proteolytic, amylolytic, antimicrobial activity. 
Cereals are one of the most important food sources worldwide for both humans and animals. They supplies a considerable portion of the nutrients required for growth, well-being and maintenance of health (FAO 2002; FAO 2014). In the past, many populations of several cultures are directly linked to cereals and, thus are recognized by the cereals they eat. This is the case of Mediterranean people which are recognized to be "wheat people" (Alfonzo et al. 2013). Tunisia is placed among the largest wheat per capita consumers in the world with a total of 2.8 million metric tons MT per year between 2016/2017 (USDA 2016). Moreover, wheat bread is the most popular staple food consumed in Tunisia under different forms such as backer's yeast bread, Tabouna, Mlawi, Mtabga (Mamhoud et al. 2016).

However, cereal grains, including wheat, are naturally contaminated by microorganisms (yeast, moulds and bacteria) which can occur in the field during growth, harvest, post-harvest and storage (Eglezos 2010). During milling, a small fraction of microorganisms initially concentrated in the outer layers of kernels, could contaminate the flour, leading to microbial rate increase during storage (Berghofer et al. 2003). The microflora composition and the relative species ratio on wheat grains are influenced by several factors including temperature, moisture, physical damage caused by molds and application of pesticides (Karlsson et al. 2014; Fleurat-Lessard 2017). Several works highlights that flour's wheat are dominated by fungi. Food spoilage by moulds and the occurrence of their mycotoxins constitute a potential health hazard (Čonková et al. 2006). Among the microorganisms associated with flours, lactic acid bacteria (LAB) play an important role in preserving the balance of microbial flora and enhancing the shelf life of final products by controlling and inhibiting spoilage organisms during fermentation, due to their antimicrobial properties (Dalié et al. 2010; Cizeikiene et al. 2013).

117 LAB are commonly present in various habitats, including milk and dairy products, vegetables, meat and cereal products, where fermentation can take place (Giraffa 2014) and they constitute the majority of the rate of the commercial starter cultures (Corsetti and Settanni 2007; De Vuyst et al. 2009; Guyot 2010). LAB have been isolated, identified and characterized from cereals (Mamhoud et al. 2016) or mature sourdoughs (Digaitiene et al. 2012) or fermented dough (Mhir et al. 2007).

122 However, few studies were focused on the characterization of LAB isolated from wheat flours (Corsetti et al. 123 2007; Alfonzo et al. 2013). To our knowledge, there are no previous studies focused on the characterization of lactic acid bacteria isolated from Tunisian wheat flours.

125 Despite the availability of essential nutrients for LAB growth, the investigation of flour's LAB content remains difficult and critique because of the low water content (Alfonzo et al. 2013). Indeed, within flours, several LAB species are found in a dormant state (Corsetti et al. 2007). Some studies showed that Lactobacillus and Enterococcus were the most abundant in Italian flours (Corsetti et al. 2007; Robert et al. 2009). The aims of this study were to: (i) enumerate total mesophilic aerobic microorganisms, yeasts, fungi and LAB in flour samples; (ii) isolate, identify and characterize LAB naturally occurring on Tunisian wheat flour; (iii) and evaluate the technological capabilities of LAB by examining their acidifying ability in a flour extract system, proteolytic, amylolytic, antibacterial and antifungal activities for a further incorporation as starter in sourdough formulation. 
Six samples of baking wheat flours were collected from mills situated in different geographical regions of Tunisia (Nabeul, Tunis, Sousse, Djerba and Sfax), and used for microbiological analysis of total mesophilic aerobic microorganisms, yeasts, moulds and Lactic acid bacteria (LAB) (Table 1). Ten grams of flour were

139

140

141

142

143

144

145

146

147

148

149

150

151

152

153

154

155

156

157

158

159

160

161

162

163

164

165

166

167

168

169

170

171

172

173 homogenized with $90 \mathrm{~mL}$ of sterile peptone water solution (peptone $0.1 \%$ and $\mathrm{NaCl} 0.85 \%$ ) (Minervini et al. 2015). Total mesophilic aerobic microorganisms, yeasts and moulds were enumerated using the PCA (Plate Count Agar) and SD (Sabouraud Dextrose) agar media with chloramphenicol 5\%, respectively (Minervini et al. 2015). Lactic acid bacteria (LAB) were enumerated using MRS medium (Man, Rogosa, Sharpe agar) supplemented with $0.01 \%$ of cycloheximide (MP Biomedicals) to avoid fungal growth and $0.0025 \%$ of bromocresol green (MP Biomedicals) to indicate acidification of the medium (yellow turn) by LAB.

\section{Isolation of lactic acid bacteria}

The isolation of lactic acid bacteria was carried by enriching $10 \mathrm{~g}$ of each sample into $90 \mathrm{~mL}$ of modified-MRS (mMRS) broth (1\% maltose, $1 \%$ lactose and $10 \%$ yeast extract). Cultures were incubated at $30^{\circ} \mathrm{C}$ for 3 days. Then $1 \mathrm{~mL}$ of each resulting culture was diluted using decimal dilutions and plated in MRS agar supplemented with $0.0025 \%$ of bromocresol green (MP Biomedicals) and 0.01\% cycloheximide (MP Biomedicals) and incubated under anaerobic conditions at $30{ }^{\circ} \mathrm{C}$ for $48-72 \mathrm{~h}$. Acid-producing bacteria characterized by a yellow zone around each colony were picked and purified on MRS agar. Gram-positive and catalase negative isolates were restreaked and cultivated into the same agar medium. The pure cultures were maintained in $20 \%$ of glycerol (v/v) and conserved at $-80{ }^{\circ} \mathrm{C}$.

\section{DNA extraction, characterization and molecular identification of lactic acid bacteria}

Genomic DNA was extracted according to the method described by Wilson (2001) using CTAB/NaCl method. Bacterial strains were characterized genotypically by profile analysis of the 16S-23S rDNA Internal Transcribed Spacer (ITS) region using universal primers (s-d-bact-1494a-20 and s-d-bact-0035-a-15) (Daffonchio et al. 1998). Bacteria strains presenting the same band patterns were clustered in the same ITS-haplotype. One or two representative strains from each cluster have been selected for 16S rDNA gene PCR amplification which was performed using universal primers (s-d-bact-0008-a-S-20 and s-d-bact-1495-a-A20) according to Daffonchio et al. (1998). The two PCR were performed on a thermocycler (BioRad) using this program: $94{ }^{\circ} \mathrm{C}$ for $3 \mathrm{~min}, 35$ cycles of $94{ }^{\circ} \mathrm{C}(45 \mathrm{~s}), 55{ }^{\circ} \mathrm{C}(1 \mathrm{~min}), 72^{\circ} \mathrm{C}$ for $2 \mathrm{~min}$ and a final cycle at $72{ }^{\circ} \mathrm{C}$ for $10 \mathrm{~min}$. PCR products were separated by electrophoresis through $1.5 \%(\mathrm{w} / \mathrm{v})$ agarose gel containing ethidium bromide $(0.5 \mathrm{mg} / \mathrm{mL})$.

The 16S rDNA PCR amplicons were purified with Exonuclease-I and Shrimp Alkaline Phosphatase (Exo-Sap, Fermentas, Life Sciences) based on the manufacturer's standard protocol. DNA sequencing was performed in an automated capillary DNA sequencer (Applied Biosystems 3130XL) using a Big Dye Terminator cycle sequencing Kit V3.1 (Applied Biosystems). Sequence identification to the closet relative taxa of the strains was achieved using BLAST analysis tool (Tamura et al. 2011) in the GenBank DNA database (www.ncbi.nih.gov). Phylogenetic analysis of 16S rRNA gene sequences was conducted with MEGA-6 software (Tamura et al. 2011). Phylogenetic tree was constructed by using neighbor-joining method (Saitou and Nei 1987). 


\section{Acidification activity}

To evaluate the acidification activity of isolated LAB, a sterile flour extract (SFE) was prepared according to the method described by Alfonzo et al (2013): $200 \mathrm{~g}$ of flour was suspended in distilled water $(1 \mathrm{~L})$ and sterilized at $121{ }^{\circ} \mathrm{C}$ for $20 \mathrm{~min}$. After precipitation, the flour was removed. The supernatant was used as liquid broth in subsequent experiments. Overnight LAB cultures on MRS broth were centrifuged (5000 x g for $5 \mathrm{~min}$ and washed 3 times with sterile distilled water. LAB cells were inoculated in $50 \mathrm{~mL}$ of the solution SFE with $1 \%$ (v/v) of bacterial suspension at $10^{9} \mathrm{CFU} / \mathrm{mL}$ and incubated at $30{ }^{\circ} \mathrm{C}$. The $\mathrm{pH}$ measurements were taken initially, after $24 \mathrm{~h}, 48 \mathrm{~h}$ and $72 \mathrm{~h}$ of inoculation.

Strains that rapidly and greatly decreased SFE $\mathrm{pH}$, were analyzed for their ability to produce lactic and acetic acids, following 24, 48 and 72h of fermentation. Each resultant sample of acidified SFE (aSFE), was mixed with $1 / 10$ mixture of ethyl-butyric acid $2 \mathrm{mg} \mathrm{mL}$ (internal standard), filtered through $0.2-\mu \mathrm{m}$ filters and stored at -80 ${ }^{\circ} \mathrm{C}$ until analysis. A system composed of a 7020A gas chromatograph (Agilent Technologies Inc., Palo Alto, CA) connected to a mass spectrometry (MS) $5975 \mathrm{~N}$ detector (Agilent) was used to quantify the short chain fatty acids SCFA. Data were collected with Enhanced ChemStation G1701DA software (Agilent). $1 \mu 1$ were directly injected into the gas chromatograph equipped with a ZB-WAX capillary column (30-mm length by $250 \mu \mathrm{m}$ internal diameter, with a $0.25 \mu \mathrm{m}$ film thickness; Agilent) using $\mathrm{H}_{2}$ as the gas carrier, with a constant flow rate of $1.5 \mathrm{~mL} / \mathrm{min}$. The temperature of the injector was kept at $220{ }^{\circ} \mathrm{C}$, and the injection was performed in split less mode. Chromatographic conditions were as follows: an initial oven temperature of $50{ }^{\circ} \mathrm{C}, 5{ }^{\circ} \mathrm{C} / \mathrm{min}$ up to $180{ }^{\circ} \mathrm{C}$, $1 \mathrm{~min}$ at $180^{\circ} \mathrm{C}$, and $20^{\circ} \mathrm{C} / \mathrm{min}$ up to $220^{\circ} \mathrm{C}$ for cleaning the column. The column was directly connected to the MS detector, and the electron impact energy was set to $70 \mathrm{eV}$. The data collected were in the range of 25 to 250 atomic mass units $(3.25 \mathrm{scans} / \mathrm{s})$. The organic acids were identified by comparing their mass spectra with those held in the NSIT MS Data Center and 2HP-Wiley 138 library (Agilent) and by comparing their retention times with those of the corresponding standards (Volatile Free fatty acid mixture CRM46975) purchased from Sigma. The peaks were quantified as the relative total ionic count abundance with respect to the internal standard. The concentration estimated in $\mathrm{mM}$ of each acid was calculated using linear regression equations $\left(R^{2} \geq 0.99\right)$ from the corresponding curves of standards obtained with eight different concentrations.

\section{Proteolytic activity}

203 Extracellular proteolytic activity of LAB strains inoculated for $72 \mathrm{~h}$ in SFE, was measured according to the method described by Miralles et al (1996) using Azocasein as substrate. Absorbance was measured at $440 \mathrm{~nm}$ against a blank containing only the Azocasein. Proteolytic activity was expressed as $\Delta \mathrm{DO}_{440} \times \mathrm{h}^{-1} \times \mathrm{mg}^{-1} \mathrm{dry}$ weight.

\section{Antioxidant activity}

209 The antioxidant activity was measured using DPPH according to the method described by Lin and Chang (2000). LAB were harvested by centrifugation at $4400 \mathrm{x}$ g for $10 \mathrm{~min}$ after culture of $18 \mathrm{~h}$ incubation at $37^{\circ} \mathrm{C}$. The test was performed on the intact bacterial cells. Cells were washed three times with phosphate buffer solution (PBS: $0.85 \% \mathrm{NaCl}, 2.68 \mathrm{mM} \mathrm{KCl}, 10 \mathrm{mM} \mathrm{Na} 2 \mathrm{HPO}_{4}$, and $1.76 \mathrm{mM} \mathrm{KH}_{2} \mathrm{PO}_{4}, \mathrm{pH}$ 7.4) and resuspended in the same buffer. The sample $(0.8 \mathrm{~mL})$ was reacted with $1 \mathrm{~mL}$ DPPH solution $(0.2 \mathrm{mM}$ in $0.5 \%$ ethanol). The control was 

by spectrophotometer (Thermo Scientific Multiskan GO) at $517 \mathrm{~nm}$ in triplicate. The results are expressed as a percentage of the anti-radical activity:

$$
\text { Antioxidant activity }(\%)=\left[\frac{A_{517 \text { control }}-A_{517 \text { sample }}}{A_{517 \text { control }}}\right] \times 100
$$

217

218

219

220

221

222

223

224

225

226

227

228

229

230

231

232

233

234

235

236

237

238

239

240

241

242

243

244

245

246

247

248

249

\section{Amylolytic activity}

The amylolytic activity of LAB was measured using the starch-iodine method, described by Bartkiene et al (2013).To evaluate this activity, the sterile flour extract SFE was enriched with glucose $0.15 \%$ in order de enhance the bacterial growth. The absorbance was measured at $670 \mathrm{~nm}$ using a spectrophotometer (Thermo Scientific Multiskan GO). One unit of $\alpha$-amylase activity (1 AU) was defined as an amount of enzyme that catalyzes $1 \mathrm{~g}$ soluble starch hydrolysis to dextrins in $10 \mathrm{~min}$ at $30{ }^{\circ} \mathrm{C}$ temperature.

\section{Antimicrobial activity}

The antimicrobial activities of LAB were determined against pathogenic bacterial and fungal strains. Enterococcus faecalis ATCC 29212, Escherichia coli DH5a, Pseudomonas aeruginosa ATCC 27853 and Staphylococcus aureus ATCC 25923 were used as indicator strains. These pathogens were grown in Brain heart infusion (BHI) broth at $37^{\circ} \mathrm{C}$. The inhibitory activity was evaluated with spots method. The colonies of LAB were grown in MRS medium incubated for $24 \mathrm{~h}$ at $30^{\circ} \mathrm{C}$. The indicator strains were inoculated at $10^{5} \mathrm{CFU} / \mathrm{mL}$ in $5 \mathrm{~mL}$ of soft agar (containing $0.75 \%$ agar) and poured into petri dishes which were then incubated anaerobically at $37^{\circ} \mathrm{C}$ for $24 \mathrm{~h}$. Antimicrobial activity was expressed as inhibition diameter zones in millimeter $(\mathrm{mm})$ against the pathological strains. The zone of inhibition was divided as follows: strong inhibitor $(\mathrm{d} \geq 15$ $\mathrm{mm})$, medium inhibitor $(11 \leq \mathrm{d}<15 \mathrm{~mm})$, no significant inhibitory effect $(\mathrm{d}<11 \mathrm{~mm})$.

The antifungal activity of LAB was evaluated against two fungi Aspergillus niger and Penicillium expansum according to the method described by Whipps (1987). LAB were inoculated on the modified MRS agar (without ammonium citrate and sodium acetate), $2 \mathrm{~cm}$ from the edge line of the petri dish and then grown at $30{ }^{\circ} \mathrm{C}$ for 48 h. A piece of fungus was placed in the center of the petri dish and then incubated at $25{ }^{\circ} \mathrm{C}$ for 2 to 3 days. Control plates were inoculated with fungi only. The antifungal activity of LAB was expressed according to the following formula:

$$
\text { Antifungal activity }(\%)=\left[\frac{\mathrm{R} 2-\mathrm{R} 1}{R 1}\right] * 100
$$

$\mathrm{R} 1$ is the radial distance developed by fungi in the direction of antagonism; $\mathrm{R} 2$ is the radial distance developed by the fungi.

\section{Production of exopolysaccharides}

The measurement of the amount of exopolysaccharides was done by the colorimetric test developed by Dubois et al (1956).The supernatant $(0.4 \mathrm{~mL})$ of an overnight culture of LAB strain was mixed with $0.2 \mathrm{~mL}$ of phenol solution $(5 \%)$ and $0.5 \mathrm{~mL}$ of concentrated sulfuric acid. After incubation in the dark for 30 minutes, the absorbance was measured at $490 \mathrm{~nm}$ against a blank without LAB strain. 


\section{Statistical analysis}

251

252

253

254

255

256

257

258

259

260

261

262

263

264

265

266

267

268

269

270

271

272

273

274

275

276

277

278

279

280

281

282

283

284

285

286

287

288

All experiments were repeated three times and illustrated as the mean values \pm standard deviations. Statistical analyses were performed using the IBM SPSS Statistics software version 23.0. The data were analyzed using one-way analysis of variance (ANOVA), followed by the Duncan's test with the significance level set at $p<0.05$ to establish the significance of differences between the samples.

\section{Results and discussion}

\section{Microflora of wheat flour}

Examination of the microbiological quality of wheat flour samples was performed in order to gain a common view about the hygienic quality and microbiological load. The microbial content of flours is composed of mesophilic aerobic bacteria, yeasts, moulds, and lactic acid bacteria. The results of microbiological analysis showed that yeasts constituted the major microbiota of the flour samples (Table 1). Yeast counts ranged from 0.30 to $2.57 \mathrm{Log} \mathrm{CFU} / \mathrm{g}$, whereas presumptive $\mathrm{LAB}$ counts varied from 0.17 to $1.68 \mathrm{Log} \mathrm{CFU} / \mathrm{g}$. The mean mesophilic aerobic bacteria counts in all flour samples studied were 1.53 to $2.11 \mathrm{Log}$ CFU/g. All samples were below the maximum acceptable limits of the Codex Alimentarius (FAO 1995b). According to Minervini et al. (2015), LAB contaminating flour is strongly affected by the endophytic microbiota of cereals, mainly by the plant organs, the cultivars, and the phenological growth stages. A number of plant-associated microorganisms infect grains, and so flours, touching the whole quality of leavened baked goods (De Vuyst et al. 2009; Gobbetti et al. 2014).

\section{Isolation and identification of lactic acid bacteria}

LAB were isolated from Tunisian wheat flours collected from six different regions (Table 1). Upon enrichment in MRS broth 113 LAB isolates were initially selected based on their ability to produce acid by the presence of yellow halo surrounding the colonies on MRS-bromocresol green plates and purified. A total of 45 isolates Gram-positive and catalase-negative rods and cocci were kept on MRS agar for further identification.

The isolates were subjected to ITS-PCR amplification analysis and 16S-PCR sequencing. In fact, diverse studies have previously described the efficiency of ITS for inter- and intra-differentiation at the genus/ species level (Gürtler and Stanisich 1996) due to the high variability of these spacers. The ITS-PCR amplification generated different patterns (bands ranging from 50 to 1000 base pairs). Comparing the generated patterns of PCR products obtained from the studied isolates, we distinguished 09 ITS fingerprints. One representative of each ITS-PCR pattern were subjected to partial sequencing of the 16S rRNA. LAB isolates were identified at species level by $16 \mathrm{~S}$ rRNA gene sequencing which is generally regarded as a more reliable solution for the classification and identification of LAB (Ehrmann and Vogel 2005). According to the comparison of 16S rDNA sequences with those available in GenBank, all isolates were related to LAB species with sequence homology $>97 \%$. Phylogenetic tree of LAB isolated from wheat flours was constructed based on the 16S rDNA sequences from evolutionary distances by the neighbor-joining method (Figure 1). LAB identification showed several consistent recognized species that are affiliated to four lactic genotypic groups (Figure 1). LAB strains were identified to: Weissella cibaria (05 strains), Lactobacillus plantarum (08 strains), Lactobacillus brevis (04 strains), Pediococcus pentosaceus (10 strains), Pediococcus pentoseus (04 strains), Pediococcus acidilactici (04 strains), 

strains).

291 In our studies, several LAB species found were reported to be associated with bread production, such as wheat grains and flours (Corsetti et al. 2007). In addition, some of LAB species isolated in our wheat flours are naturally found in mature sourdoughs such as L. plantarum (Corsetti and Settanni 2007; Alfonzo et al. 2013) and W. cibaria (Alfonzo et al. 2013). We noted that Pediococcus genus was presented by $P$. pentosaceus (followed by $P$. pentoseus and $P$. acidilactici) as the most commonly isolated bacterium from wheat flours. P. acidilactici is emerging as a potential probiotic in animal and human (Guerra et al. 2007).

The dominant species of Lactobacillus found from wheat flours was L. plantarum followed by L. brevis. This finding reinforced the concept that $L$. plantarum has a strong ecological or metabolic adaptability to different habitats (Alfonzo et al. 2013; Minervini et al. 2015). However, these two Lactobacillus species were reported to dominate raw and fermented vegetables (Rhee et al. 2011). Similar findings were noted for P. pentosaceus (Yang and Chang 2010; Swain et al. 2014). Together with L. plantarum and W. cibaria are generally isolated from plants, wheat grains and fermented wheat products (sourdough) (Corsetti et al. 2007; Trias et al. 2008; Alfonzo et al. 2013). For Enterococcus genus, En. faecium was the most commonly species presented followed by En. casseliflavus and En. faecalis. In fact, enterococci are normal inhabitants of gastrointestinal tract (Giraffa 2002). The isolated Enterococcus strains were discarded from further studies to avoid risks for antibiotic resistance and virulence gene dissemination which contribute to the pathogenesis of virulent bacteria (Bortolaia et al. 2016). Weissella genus was represented at low occurrence by only W. cibaria species. Recording to our findings, there was no correlation between LAB species and the geographical location of the wheat flour samples.

\section{Assessment of the technological properties of LAB isolates}

\section{Acidification activity}

313 In order to select lactic bacteria with technological characteristics relevant for sourdough process, 06 selected representative LAB species from wheat flour samples were investigated for the acidification capacity to decrease $\mathrm{pH}$ of sterile flour extract SFE. The results of the acidification activity are shown in Figure 2. We note that all tested LAB strains presented good acidifying abilities. They were able to decrease the SFE $\mathrm{pH}$ significantly $(p<0.05)$ below 4.0 after $24 \mathrm{~h}$. At $72 \mathrm{~h}$, almost all tested LAB strains acidified the medium below pH 3.0. Except $P$. acidilactici $\mathrm{S} 16$, the remained strains were fast acidifiers revealing a $\Delta \mathrm{pH}$ (difference between $\mathrm{pH}$ before and after inoculation of SFE by strains) around 2.8 after $24 \mathrm{~h}$ and a final $\mathrm{pH}$ (after $72 \mathrm{~h}$ ) ranging between 2.0 and 3.0. The acidifying ability of the majority of the identified LAB strains after $24 \mathrm{~h}, 48 \mathrm{~h}$ and $72 \mathrm{~h}$ incubation were similar. Compared to initial $\mathrm{pH}$ of incubated culture, Lactobacillus plantarum $\mathrm{S} 28$ showed the rapid acidification ability $\Delta \mathrm{pH}$ to decrease $\mathrm{pH}$ significantly $(p<0.05)$ of the flour extract broth at $24 \mathrm{~h}(4.84 \pm 0.2)$. This finding result concurred with previous studies of Ventimiglia et al. (2015) which reported that L. plantarum is the highest acid-producing species of LAB group. It causes rapid acidification of the raw material through the production of organic acids, mostly lactic acid. Besides, it is an abundant food related species reported to be common as well for sourdough environments (Corsetti and Settanni 2007). Accordingly, their fast lowering of the $\mathrm{pH}$ ability improves safety and organoleptic properties of fermented food products (Hansen 2002). 
The concentration of lactic and acetic acids in SFE was carried out on four strains (P. acidilactici, P. pentoseus, L. plantarum and L. brevis), that displayed interesting technological properties, after 24,48 and $72 \mathrm{~h}$ of fermentation (Figure 3). Lactic acid concentration increased after $48 \mathrm{~h}$ for all LAB strains. It reached 5.73 - 8.36 $\mathrm{mg} / \mathrm{g}$. After $72 \mathrm{~h}$, the content increased significantly $(p<0.05)$ and reached $7.77 \mathrm{mg} / \mathrm{g}$ for $P$. acidilactici and 7.06 $\mathrm{mg} / \mathrm{g}$ for $P$. pentoseus. However, we noted a significant $(p<0.05)$ decline of lactic acid concentration after $72 \mathrm{~h}$ for L. plantarum $(6.18 \mathrm{mg} / \mathrm{g})$ and L. brevis $(6.79 \mathrm{mg} / \mathrm{g})$. Acetic acid production ranged from 0 to $3.87 \mathrm{mg} / \mathrm{g}$ after $24 \mathrm{~h}$, and 3.74 to $5.95 \mathrm{mg} / \mathrm{g}$ after $72 \mathrm{~h}$. In fact, acetic acid can occur via the citrate metabolism (Zalán et al. 2010) or the degradation of lactic acid produced (Oude Elferink et al. 2001) which may justify the reduction of lactic acid concentration in SFE extract of $L$. plantarum and $L$. brevis The strains displayed a fermentation quotient (FQ: molar ratio between lactic and acetic acids) varied from 0.84 to 2.38, which is considered to affect the organoleptic features (aroma and texture) and to prevent ripeness and fungi spoilage of final products and so to guarantee longer shelf life (Gobbetti et al. 2000; Datta and Henry 2006). P. pentoseus S14 and P. acidilactici S16 presented FQ close to the optimal range of 2.0- 2.7 suggested by Hammes and Gänzle (1998).

\section{Proteolytic activity}

The proteolytic activity of tested LAB was determined by their inoculation in sterile flour extract SFE. The extracellular proteolytic activity assessed by azocasein degradation was detected in all flour LAB strains (Figure 4). P. pentoseus $\mathrm{S} 14$ and L. brevis $\mathrm{S} 12$ exhibited significantly $(p<0.05)$ highest proteolytic activity $(1.51 \pm 0.18$ and $1.41 \pm 0.14$, respectively). The extracellular protease activity is known to improve organoleptic features of leavened baked goods by generating small peptides and free amino acids as precursors for flavor development (Cagno et al. 2002; Rizzello et al. 2014). Moreover, the extracellular protease activity is important for the rheology and staleness of breads (Corsetti et al. 2000). Moreover, proteolysis generated small peptides which are important for rapid microbial growth and acidification during fermentation (Cagno et al. 2002). In addition, certain LAB strains are further known to be able to release bioactive peptides from proteins, which are thought to have a role in promoting health (Leroy et al. 2006). This finding revealed the potential use of these LAB in bread making.

\section{Antioxidant activity}

The DPPH scavenging activity of the six LAB strains from flour samples are shown in Figure 5. The results showed DPPH scavenging activity ranging between 4.39 to $25.57 \%$. Among the tested strains, W. cibaria S25 had significantly $(p<0.05)$ the highest radical-scavenging activity with a rate of $25.57 \%$, followed by $L$. brevis S12 with $24.81 \%$ and $P$. pentosaceus S30 with $21.49 \%$. Several authors have reported that the fermentation by lactic acid bacteria with antioxidant activity is considered as one of the most important tool suitable to enhance the functional and the organoleptic potential of several fermented cereal flours (Coda et al. 2012; Rizzello et al. 2013; Curiel et al. 2015).

The biodiversity of amylolytic lactobacilli, ubiquitously used in cereals processing, is quite limited (Reddy et al 2008). In this work, the in-vitro amylolytic activity of the tested LAB was evaluated by starch-iodine method. According to the results presented in Figure 4, all tested LAB are characterized by starch hydrolysis. They 
showed amylase activity ranging from $658 \pm 13$ to $1386 \pm 4 \mathrm{U} / \mathrm{mL}$ (for $1 \mathrm{~g}$ of starch hydrolyzed (SH)) which are equivalent to 6.58 to $13.86 \mathrm{U} / \mathrm{ml}$ (for $0.01 \mathrm{~g}$ of $\mathrm{SH}$ ). L. plantarum S28 demonstrated significantly $(p<0.05)$ the highest amylolytic activity $(1386 \pm 4 \mathrm{U} / \mathrm{mL})$ followed by $P$. acidilactici $\mathrm{S} 16(1086 \pm 6 \mathrm{U} / \mathrm{mL})$ and $P$. pentoseus S14 $(1046 \pm 9 \mathrm{U} / \mathrm{mL})$. These results obtained for the amylolytic activity are in line with previous reports (Petrova et al. 2010; Amapu et al. 2016). Production of amylase has been described primordially for $L$. plantarum (Giraud et al. 1994). Besides, the amylolytic activity recorded for tested LAB strains was equivalent to $8-11.5 \mathrm{U} / \mathrm{ml}$ reported for amylolytic strains (Petrova et al. 2010). In fact, high amylolytic activity was reported for L. plantarum, P. acidilactici and L. brevis which are predominant amylase producing LAB in wet milled cereals (Amapu et al. 2016). Besides, Sanni et al. (2002) described amylolytic strains of $L$. plantarum in several traditional amylaceous fermented foods. The potential LAB strain with amylolytic activity could be used as one of the factors to improve the fermentation rate, reduction of dough viscosity with resultant improvements in the volume and texture of the bread for food industries (making of high density gruels, baking, brewing) (Fossi and Tavea 2013). Ray and Montet (2016) reported that they are also employed in preparing high energy density (ED) cereal-based foods for improving dietary starch utilization in infants and small children. On the basis of their technological potentials, the strains L. plantarum S28, P. acidilactici S16, P. pentoseus S14, W. cibaria S25 and L. brevis S12 isolated from wheat flours retains better starch degradation ability. It may developed into starter cultures (sourdoughs) in the making of fermented cereal foods, including bread, to contribute to the enzymatic pool and yield products with a higher fermentable sugar content (Amapu et al. 2016; Hattingh et al. 2015). The hypothesis that the amylolytic activity of strains studied are cell wall bound or/and produced in cell-free supernatants needs to be verified.

\section{Exopolysaccharide production}

The cell-free supernatants of selected LAB strains were examined for the amounts of exopolysaccharide (EPS) yields using phenol-sulfuric acid method. EPS production of each strain was presented in Figure 6. EPS amount produced by selected LAB isolates ranged from 0.172 to $0.970 \mathrm{~g} / \mathrm{L}$. Figure 6 obviously demonstrates that the strains $P$. acidilactici S16 and L. plantarum S28 showed significantly $(p<0.05)$ highest EPS production $(0.97$ and $0.636 \mathrm{~g} / \mathrm{L}$, respectively). Several health benefits have been attributed to exopolysaccharides EPS from LAB which are used to improve the textural properties of fermented foods (Crescenzi 1995; Ruas-Madiedo et al. 2008). These strains can be used in sourdough and may have applications in bread making.

\section{Antibacterial activity} In order to select bacterial strains with antibacterial activity, selected LAB were assessed against four pathogens (Enterococcus faecalis, Escherichia coli, Pseudomonas aeruginosa and Staphylococcus aureus) as indicator strains. Table 2 gives the results for antibacterial activity of the LAB isolates in terms of inhibition diameter around the spot. All of LAB strains presented aptitude to inhibit the growth of tested pathogens with different percentages. The antibacterial activity was recorded as strong growth inhibition against Pseudomonas aeruginosa for L. brevis S12 (15 mm), P. pentoseus S14 (16 mm), W. cibaria S25 $(17 \mathrm{~mm})$ and mostly for $P$. pentosaceus S30 $(18 \mathrm{~mm})$. Except $P$. acidilactici $\mathrm{S} 16$, the entire tested LAB showed a significant $(p<0.05)$ moderate antagonistic activity towards E. coli and St. aureus. L. brevis S12 and P. pentoseus S14 presented high values of diameter of growth inhibition against St. aureus $(14.5 \mathrm{~mm})$ and $E$. coli $(12 \mathrm{~mm})$, respectively. Only $L$. 
brevis $\mathrm{S} 12$ and $P$. pentosaceus $\mathrm{S} 30$ presented significantly $(p<0.05)$ a medium growth inhibition activity against En.faecalis with an average of $11 \mathrm{~mm}$. In our case, we observe that the inhibition of microbial growth by the six $\mathrm{LAB}$ is due to $\mathrm{pH}$ variation on culture media and might be a result of fermentative compounds accumulation. $\mathrm{LAB}$ are known to produce a range of metabolic end compounds that are able of interfering with the growth of certain undesirable microbes in food systems (Vandenbergh 1993; Alvarado et al. 2006). In fact, most of the inhibitory activity exhibited by LAB strains was attributed to $\mathrm{pH}$ reduction by organic acids. Besides, it is suggested that acid products interfere with permeability of plasmic membrane and raise its diffusion leading to stop metabolic activities and so to the inhibition effect of sensitive microorganisms (Piard and Desmazeaud 1991). So, these findings led to suggest that sourdough and bread produced with these tested LAB strains, showing consistent ability to retard the growth of both pathogen moulds and bacteria species, thus have the potential to improve the shelf-life of wheat bread.

\section{Antifungal activity}

All the studied lactic acid bacteria strains, isolated from different wheat flour samples, were assessed for inhibitory activity against two common post-harvest fungus Aspergillus niger and Penicillium expansum using a dual culture method. Varying degrees of inhibition were detected against the two moulds in-vitro (Figure 7). All LAB strains exhibited significant $(p<0.05)$ inhibitory effects towards the tested fungi. The growth of Penicillium expansum was strongly inhibited by $P$. pentoseus S14 with an inhibitory rate of $84 \%$. While growth of Aspergillus niger was moderately $(p<0.05$ ) inhibited by all the tested LAB isolates from $16.7 \%$ to $36.1 \%$ of inhibition. Almost all strains, especially L. plantarum S28 and $P$. acidilactici S16, showed radial $(p<0.05)$ growth reductions against $P$. expansum and A. niger by an average of $36 \%$ and $25 \%$, respectively. Penicillium expansum was the most sensitive strain in dual-culture method. Dal Bello et al. (2007) and Djossou et al. (2011) reported that $L$. plantarum isolated from sourdough and plant materials is known by its antifungal activity. This study revealed that Tunisian wheat flours included autochthonous and selected LAB of interesting technological features relevant to sourdough production. In fact, the obtained results might be helpful to use a mixed starter culture including L. plantarum, L. brevis, P. acidilactici and P. pentoseus for producing sourdough bread.

\section{Acknowledgments}

This work was supported by the Tunisian Ministry of Higher Education and Scientific Research (LR10CBBC02). Aurelie sauvager (CORINT, UMR CNRS ISCR 6226, UFR Sciences Pharmaceutiques et Biologiques, Université Rennes 1, France) is acknowledged for her technical help.

\section{References}

443 Alfonzo A, Ventimiglia G, Corona O, Di Gerlando R, Gaglio R, Francesca N, Moschetti G, Settanni L (2013) Diversity and technological potential of lactic acid bacteria of wheat flours. Food Microbiol 36(2): 343-354. Alvarado C, García Almendárez BE, Martin SE, Regalado C (2006) Food-associated lactic acid bacteria with antimicrobial potential from traditional Mexican foods. Rev Latinoam Microbiol 48(3-4): 260-268. 


\section{8. https://doi.org/10.9734/BMRJ/2016/24509}

Bartkiene E, Jakobsone I, Juodeikiene G, Vidmantiene D, Pugajeva I, Bartkevics V (2013) Study on the reduction of acrylamide in mixed rye bread by fermentation with bacteriocin-like inhibitory substances producing lactic acid bacteria in combination with Aspergillus niger glucoamylase. Food Control 30: 35-40.

Berghofer LK, Hocking AD, Miskelly D, Jansson E (2003) Microbiology of wheat and flour milling in Australia. Int J Food Microbiol 85(1): 137-149. https://doi.org/10.1016/S0168-1605(02)00507-X

Bortolaia V, Espinosa-Gongora C, Guardabassi L (2016) Human health risks associated with antimicrobialresistant enterococci and Staphylococcus aureus on poultry meat. Clin Microbiol Infect 22(2): 130-140.

Cagno RD, Angelis MD, Lavermicocca P, Vincenzi MD, Giovannini C, Faccia M, Gobbetti M (2002) Proteolysis by Sourdough Lactic Acid Bacteria: Effects on Wheat Flour Protein Fractions and Gliadin Peptides Involved in Human Cereal Intolerance. Appl Environ Microbiol 68(2): 623-633.

Cizeikiene D, Juodeikiene G, Paskevicius A, Bartkiene E (2013) Antimicrobial activity of lactic acid bacteria against pathogenic and spoilage microorganism isolated from food and their control in wheat bread. Food Control 31(2): 539-545. https://doi.org/10.1016/j.foodcont.2012.12.004

Coda R, Rizzello CG, Pinto D, Gobbetti M (2012) Selected Lactic Acid Bacteria Synthesize Antioxidant Peptides during Sourdough Fermentation of Cereal Flours. Appl Environ Microbiol 78(4): 1087-1096.

Čonková E, Laciaková A, ŠtyriakI, Czerwiecki L, Wilczinska G (2006) Fungal Contamination and the Levels of Mycotoxins (DON and OTA) in Cereal Samples from Poland and East Slovakia. Czech J Food Sci 24: 3340.

Corsetti A, Gobbetti M, De Marco B, Balestrieri F, Paoletti F, Russi L, Rossi J (2000) Combined Effect of Sourdough Lactic Acid Bacteria and Additives on Bread Firmness and Staling. J Agric Food Chem 48(7): 3044-3051. https://doi.org/10.1021/jf990853e

Corsetti A, Settanni, L (2007) Lactobacilli in sourdough fermentation. Food Res Int 40(5): 539-558. https://doi.org/10.1016/j.foodres.2006.11.001

Corsetti A, Settanni L, Chaves López C, Felis GE, Mastrangelo M, Suzzi G (2007) A taxonomic survey of lactic acid bacteria isolated from wheat (Triticum durum) kernels and non-conventional flours. Syst Appl Microbiol 30(7): 561-571. https://doi.org/10.1016/j.syapm.2007.07.001

Crescenzi V (1995) Microbial polysaccharides of applied interest: ongoing research activities in Europe. Biotechnol Prog 11(3): 251-259. https://doi.org/10.1021/bp00033a002

Curiel JA, Pinto D, Marzani B, Filannino P, Farris GA, Gobbetti M, Rizzello CG (2015) Lactic acid fermentation as a tool to enhance the antioxidant properties of Myrtus communis berries. Microb Cell Fact 7: 14, 67. https://doi.org/10.1186/s12934-015-0250-4

Daffonchio D, Borin S, Frova G, Manachini PL, Sorlini C (1998) PCR fingerprinting of whole genomes: the spacers between the $16 \mathrm{~S}$ and $23 \mathrm{~S}$ rRNA genes and of intergenic tRNA gene regions reveal a different intraspecific genomic variability of Bacillus cereus and Bacillus licheniformis. Int J Syst Bacteriol 48: 107116. https://doi.org/10.1099/00207713-48-1-107

Dal Bello F, Clarke CI, Ryan LAM, et al (2007) Improvement of the quality and shelf life of wheat bread by fermentation with the antifungal strain Lactobacillus plantarum FST 1.7. J Cereal Sci 45: 309-318. https://doi.org/10.3390/foods6120110

Dalié DKD, Deschamps AM, Richard-Forget F (2010) Lactic acid bacteria - Potential for control of mould 
growth and mycotoxins: A review Food Control 21: 370-380. https://doi.org/10.1016/j.foodcont.2009.07.011

Datta R, Henry M (2006) Lactic acid: recent advances in products, processes and technologies - a review. J Chem Technol Biotech 81(7): 1119-1129. https://doi.org/10.1002/jctb.1486

De Vuyst L, Vrancken G, Ravyts F, Rimaux T, Weckx S (2009) Biodiversity, ecological determinants, and metabolic exploitation of sourdough microbiota. Food Microbiol 26(7): 666-675.

Digaitiene A, Hansen Ås, Juodeikiene G, Eidukonyte D, Josephsen J (2012) Lactic acid bacteria isolated from rye sourdoughs produce bacteriocin-like inhibitory substances active against Bacillus subtilis and fungi. J Appl Microbiol 112(4): 732-742. https://doi.org/10.1111/j.1365-2672.2012.05249.x

Djossou O, Perraud-Gaime I, Mirleau FL, Rodriguez-Serrano G, Karou G, Niamke S, Ouzari I, Boudabous A, Roussos S (2011). Robusta coffee beans post-harvest microflora: Lactobacillus plantarum sp. as potential antagonist of Aspergillus carbonarius. Anaerobe 17(6): 267-272.

Dubois M, Gilles KA, Hamilton JK, Rebers PT, Smith F (1956) Colorimetric method for determination of sugars and related substances. Anal Chem 28(3): 350-356. https://doi.org/10.1021/ac60111a017

Eglezos S (2010) Microbiological Quality of Wheat Grain and Flour from Two Mills in Queensland, Australia. J Food Prot 73(8): 1533-1536. https://doi.org/10.4315/0362-028X-73.8.1533

Ehrmann MA, Vogel RF (2005) Molecular taxonomy and genetics of sourdough lactic acid bacteria. Trends Food Sci Technol 16(1): 31-42. https://doi.org/10.1128/AEM.02955-13

FAO (Food and Agriculture Organisation) (1995b) Norme codex pour la semoule et la farine de blé dur, CODEX STAN 178-1991, -Rév. 1-1995 : 4 p.

FAO (Food and Agriculture Organisation) (2002) World Agriculture: Towards 2015/2030. Summary Report. FAO, Rome.

FAO (Food and Agriculture Organisation) (2014) Statistical book. www.fao.org/economic.

Fleurat-Lessard F (2017) Integrated management of the risks of stored grain spoilage by seedborne fungi and contamination by storage mould mycotoxins - An update. J Stored Prod Res 71: 22-40.

Fossi BT, Tavea F (2013) Application of Amylolytic Lactobacillus fermentum 04BBA19 in Fermentation for Simultaneous Production of Thermostable Alpha-Amylase and Lactic Acid. R and D for food, health and livestock Purposes, chapter 27. https://doi.org/10.5772/50456

Giraffa G (2002) Enterococci from foods. FEMS Microbiol Rev 26:163-17.

Giraffa G (2014) Overview of the ecology and biodiversity of the LAB. In: Holzapfel WH and Wood BJB Lactic acid bacteria - biodiversity and taxonomy. Chichester, West Sussex, UK: John Wiley and Sons, Ltd. pp. 4554.

Giraud E, Champailler A, Raimbault M (1994) Degradation of raw starch by a wild amylolytic strain of Lactobacillus plantarum. J Appl Environ Microbiol 60(12): 4319-4323.

Gobbetti M, Lavermicocca P, Minervini F, De Angelis M, Corsetti A (2000) Arabinose fermentation by Lactobacillus plantarum in sourdough with added pentosans and alphaalpha-L-arabinofuranosidase: a tool to increase the production of acetic acid. J Appl Microbiol 88(2): 317-324.

Gobbetti M, Rizzello CG, Di Cagno R, De Angelis M (2014) How the sourdough may affect the functional features of leavened baked goods. Food Microbiol 37:30-40. https://doi.org/10.1016/j.fm.2013.04.012

Guerra NP, Agrasar AT, Macías CL, Bernárdez PF, Castro LP (2007) Dynamic mathematical models to describe the growth and nisin production by Lactococcus lactis subsp. lactis CECT 539 in both batch and re-alkalized 
fed-batch cultures. J Food Eng 82(2): 103-113. https://doi.org/10.1155/2010/290286

Gürtler V, Stanisich VA (1996) New approaches to typing and identification of bacteria using the 16S-23S rDNA spacer region. Microbiology (Reading, England) 142: 3-16. https://doi.org/10.1099/13500872-142-1-3

Guyot JP (2010) Fermented cereal products. In: Tamang JP and Kailasapathy K (eds) Fermented Foods and Beverages of the World. New York: CRC Press, Taylor and Francis Group, 247-261.

Hammes WP and Gänzle MG (1998) Sourdough breads and related products. In: Wood BJB (ed) Microbiology of Fermented Foods Blackie. Academic and Professional (London), pp 199-216.

Hansen EB (2002) Commercial bacterial starter cultures for fermented foods of the future. Int J Food Microbiol 78(1): 119-131.

Hattingh M, Alexander A, Meijering I, Van Reenan CA, Dicks LMT (2015) Amylolytic strains of Lactobacillus plantarum isolated from barley. Afr J Biotechnol 14(4): 310-318. http://dx.doi.org/10.5897/AJB2014.14149

Karlsson I, Friberg H, Steinberg C, Persson P (2014) Fungicide Effects on Fungal Community Composition in the Wheat Phyllosphere. PLoS ONE: 9(11):e111786.

Leroy F, Verluyten J, De Vuyst L (2006) Functional meat starter cultures for improved sausage fermentation. Int J Food Microbiol 106(3): 270-85. https://doi.org/10.1016/j.ijfoodmicro.2005.06.027

Lin MY, Chang FJ (2000) Antioxidative Effect of Intestinal Bacteria Bifidobacterium longum ATCC 15708 and Lactobacillus acidophilus ATCC 4356. Dig Dis Sci 45(8): 1617-1622.

Mamhoud A, Nionelli L, Bouzaine T, Hamdi M, Gobbetti M, Rizzello CG (2016) Selection of lactic acid bacteria isolated from Tunisian cereals and exploitation of the use as starters for sourdough fermentation. Int J Food Microbiol 225(Supplement C): 9-19.

Mhir S, Mejri M, Hamdi M (2007) Microflora distribution and species ratio of Tunisian fermented doughs for bakery industry. Afr J Biotechnol 6(18): 2122. https://doi.org/10.5897/AJB2007.000-2330

Minervini F, Celano G, Lattanzi A, Tedone L, De Mastro G, Gobbetti M, De Angelis M (2015) Lactic Acid Bacteria in durum wheat flour are endophytic components of the plant during its entire life cycle. Appl Environ Microbiol 81(19): 6736-6748.

Miralles MC, Flores J and Perez-Martinez G (1996) Biochemical tests for the selection of Staphylococcus strains as potential meat starter cultures. Food Microbiol 13(3): 227-236. https://doi.org/10.1006/fmic.1996.0028

Oude Elferink SJ, Krooneman J, Gottschal JC, Spoelstra SF, Faber F, Driehuis F (2001) Anaerobic conversion of lactic acid to acetic acid and 1, 2-propanediol by Lactobacillus buchneri. Appl Environ Microbiol 67(1):12532.

Piard JC, Desmazeaud M (1991) Inhibiting factors produced by lactic acid bacteria. 1. Oxygen metabolites and catabolism end-products. Le Lait 71(5): 525-541. https://doi.org/10.1051/lait:1991541

Petrova P, Emanuilova M, Petrov K (2010) Amylolytic Lactobacillus strains from Bulgarian fermented beverage boza. Zeitschrift für Naturforschung C 65(3-4): 218-224. https://doi.org/10.1515/znc-2010-3-409

Ray RC, and Montet D (2016) Amylolytic Lactic Acid Bacteria: Microbiology and Technological Interventions in Food Fermentations. In: Fermented Foods. CRC Press. Part I, pp 142-159.

Reddy G, Altaf Md, Naveena BJ, Venkateshwar M, Vijay KE (2008) Amylolytic bacterial lactic acid fermentation: A review. Biotechnology Advances 26:34. https://doi.org/10.1016/j.biotechadv.2007.07.004

Rhee SJ, Lee JE, Lee CH (2011) Importance of lactic acid bacteria in Asian fermented foods. Microb Cell Fact 

R, Gobbetti M (2013) Lactic acid fermentation as a tool to enhance the functional features of Echinacea spp. Microb Cell Fact 4: 12-44.

Rizzello CG, Curiel JA, Nionelli L, Vincentini O, Di Cagno R, Silano M, Gobbetti M, Coda R (2014) Use of fungal proteases and selected sourdough lactic acid bacteria for making wheat bread with an intermediate content of gluten. Food Microbiol 37: 59-68. https://doi.org/10.1016/j.fm.2013.06.017

Robert H, Gabriel V, Fontagné-Faucher C (2009) Biodiversity of lactic acid bacteria in French wheat sourdough as determined by molecular characterization using species-specific PCR. Int J Food Microbiol 135(1): 53-59. https://doi.org/10.1016/j.ijfoodmicro.2009.07.006

Ruas-Madiedo P, Abraham A, Mozzi F, de los Reyes-Gavilán CG (2008) Functionality of exopolysaccharides produced by lactic acid bacteria. In :Mayo B, Ĺopez P, Pérez-Martínez G (eds) Molecular aspects of lactic acid bacteria for traditional and new applications. Research Signpost, Kerala, India, pp 137-166.

Saitou N, Nei M (1987) The neighbor-joining method: a new method for reconstructing phylogenetic trees. Mol. Biol. Evol 4(4): 406-425.

Sanni AI, Morlon-Guyot J, Guyot JP (2002) New efficient amylase-producing strains of Lactobacillus plantarum and $L$ fermentum isolated from different Nigerian traditional fermented foods. Int J Food Microbiol 72(1): $53-62$.

Swain MR, Anandharaj M, Ray R, Parveen Rani R (2014) Fermented Fruits and Vegetables of Asia: A Potential Source of Probiotics. Biotechnol Res Int 2014:19. http://dx.doi.org/10.1155/2014/250424

Tamura K, Peterson D, Peterson N, Stecher G, Nei M, Kumar S (2011) MEGA5: molecular evolutionary genetics analysis using maximum likelihood, evolutionary distance, and maximum parsimony methods. Mol Biol Evol 28(10): 2731-2739.

Trias R, Bañeras L, Montesinos E, Badosa E (2008) Lactic acid bacteria from fresh fruit and vegetables as biocontrol agents of phytopathogenic bacteria and fungi. Int Microbiol 11(4): 231-236.

USDA (2016) Tunisia Grain and feed annual, GAIN Report Number TS1604, Foreign agriculture service, 03 March.

Vandenbergh PA (1993) Lactic acid bacteria, their metabolic products and interference with microbial growth. FEMS Microbiol Rev 12(1): 221-237. https://doi.org/10.1111/j.1574-6976.1993.tb00020.x

Ventimiglia G, Alfonzo A, Galluzzo P, Corona O, Francesca N, Caracappa S, Moschetti G, Settanni, L (2015) Codominance of Lactobacillus plantarum and obligate heterofermentative lactic acid bacteria during sourdough fermentation. Food Microbiol 51(Supplement C): 57-68. https://doi.org/10.1016/j.fm.2015.04.011

Whipps JM (1987) Effect of Media on Growth and Interactions between a Range of Soil-Borne Glasshouse Pathogens and Antagonistic Fungi. New Phytol 107(1): 127-142.

Wilson, K. (2001) Preparation of genomic DNA from bacteria. Curr Protoc Mol Biol, 2-4. https://doi.org/10.1002/0471142727.mb0204s56

Yang EJ, Chang HC (2010) Purification antifungal compound of a new produced by Lactobacillus plantarum AF1 isolated from kimchi. Int J Food Microbiol 139(1): 56-63.

Zalán Z, Hudáček J, Štětina J, Chumchalová J, Halász A (2010) Production of organic acids by Lactobacillus strains in three different media. Eur Food Res Technol 230(3): 395-404. 
Table 1. Microflora in flour samples collected from mills located throughout Tunisia (Log CFU/g).

\begin{tabular}{ccccccc}
\hline Sample & Company & $\begin{array}{c}\text { Geographical } \\
\text { origin }\end{array}$ & $\begin{array}{c}\text { Mesophilic } \\
\text { aerobic bacteria }\end{array}$ & Yeasts & Moulds & $\begin{array}{c}\text { Lactic acid } \\
\text { bacteria }\end{array}$ \\
\hline E1 & $\begin{array}{c}\text { Grands Moulins } \\
\text { de Nabeul }\end{array}$ & Nabeul & $1.89 \pm 0.17^{\mathrm{b}}$ & $2.51 \pm 0.11^{\mathrm{a}}$ & $<1^{*}$ & $1.68 \pm 0.03^{\mathrm{a}}$ \\
E5 & Epis de Carthage & Sousse & $1.72 \pm 0.11^{\mathrm{b}}$ & $2.27 \pm 0.20^{\mathrm{a}}$ & $<1^{*}$ & $1.16 \pm 0.15^{\mathrm{b}}$ \\
E6 & RANDA & Tunis & $1.89 \pm 0.14^{\mathrm{b}}$ & $2.57 \pm 0.17^{\mathrm{a}}$ & $<1^{*}$ & $1.67 \pm 0.04^{\mathrm{a}}$ \\
E7 & $\begin{array}{c}\text { Couscousseries } \\
\text { du sud }\end{array}$ & Sfax & $2.11 \pm 0.24^{\mathrm{a}}$ & $2.41 \pm 0.21^{\mathrm{a}}$ & $<1^{*}$ & $1.21 \pm 0.07^{\mathrm{b}}$ \\
E8 & Epi d'or & Sousse & $1.53 \pm 0.12^{\mathrm{c}}$ & $0.30 \pm 0.04^{\mathrm{c}}$ & $1.35 \pm 0.12^{\mathrm{a}}$ & $0.17 \pm 0.04^{\mathrm{c}}$ \\
E11 & AZIZA & Djerba & $2.04 \pm 0.21^{\mathrm{a}}$ & $1.27 \pm 0.12^{\mathrm{b}}$ & $0.39 \pm 0.07^{\mathrm{b}}$ & $0.30 \pm 0.05^{\mathrm{c}}$ \\
\hline
\end{tabular}

610

Each value represents the mean value standard deviation (SD) from two trials; a, b and $c$, represent significant $(p<0.05)$ differences in the same column; *: Counts $<1$.

612

613

614

615

616

617

618

619

620

621

622

623

624

625

626

627

628

629

630

631

632

633

634 
Table 2. Inhibitory diameter ( $\mathrm{mm}$ ) of neutralized cell-free supernatant of six selected LAB flour isolates.

\begin{tabular}{|c|c|c|c|c|}
\hline & $\begin{array}{c}\text { Enterococcus } \\
\text { faecalis ATCC } \\
29212 \\
\end{array}$ & $\begin{array}{c}\text { Pseudomonas } \\
\text { aeruginosa } \\
\text { ATCC } 27853 \\
\end{array}$ & $\begin{array}{c}\text { Escherichia } \\
\text { coli } \mathrm{DH} 5 \alpha\end{array}$ & $\begin{array}{c}\text { Staphylococcus } \\
\text { aureus ATCC } \\
25923\end{array}$ \\
\hline Pediococcus acidilactici S16 & $8.5 \pm 0.71^{\mathrm{a}}$ & $11.5 \pm 0.71^{\mathrm{b}}$ & $8 \pm 0^{\mathrm{a}}$ & $10.75 \pm 0.35^{\mathrm{a}}$ \\
\hline Pediococcus pentoseus S14 & $10 \pm 0^{b}$ & $16 \pm 0^{\mathrm{a}}$ & $12 \pm 1.41^{\mathrm{b}}$ & $11.75 \pm 1.06^{\mathrm{b}}$ \\
\hline Weissella cibaria $\mathbf{S 2 5}$ & $8 \pm 0^{\mathrm{a}}$ & $17 \pm 0^{\mathrm{a}}$ & $11 \pm 0.71^{\mathrm{b}}$ & $12 \pm 0^{\mathrm{b}}$ \\
\hline Lactobacillus brevis $\mathrm{S} 12$ & $11.5 \pm 0.71^{\mathrm{b}}$ & $15 \pm 0^{\mathrm{a}}$ & $11 \pm 0^{\mathrm{b}}$ & $14.5 \pm 0.71^{\mathrm{c}}$ \\
\hline Lactobacillus plantarum S28 & $9 \pm 1.41^{\mathrm{a}}$ & $13 \pm 0^{\mathrm{a}}$ & $11 \pm 1.41^{\mathrm{b}}$ & $12.5 \pm 0^{\mathrm{b}}$ \\
\hline Pediococcus pentosaceus S30 & $11 \pm 0^{b}$ & $18 \pm 0^{\mathrm{a}}$ & $11.5 \pm 0.71^{\mathrm{b}}$ & $11.75 \pm 0.35^{\mathrm{b}}$ \\
\hline
\end{tabular}

641

642

643

644

645

646

647

648

649

650

651

652

653

654

655

656

657

658

659

660

661

662

663

664

665

666

667

668

669

670

671

Numbers indicated the diameter of the inhibition zone in $\mathrm{mm}$; Each value represents the mean value standard deviation (SD) from two trials; $\mathrm{a}, \mathrm{b}$ and $\mathrm{c}$, represent significant $(p<0.05)$ differences in the same column. 
673 Fig. 1 Dendrogram obtained by comparing 16S rDNA sequences of the isolates from Tunisian wheat flours, 674 based on 16S rDNA partial sequences, using the neighbor-joining method. Bootstrap values for a total of 1000 675 replicates are shown at the nodes of the tree, using MEGA-6. The scale bar corresponds to 0.01 units of the 676 number of base substitutions per site.

677 Fig. 2 Kinetics of acidification of wheat flour LAB. Histograms are in the order of increasing $\mathrm{pH}$ after $24 \mathrm{~h}, 48 \mathrm{~h}$ 678 and $72 \mathrm{~h}$.

679 Fig. 3 Organic acids content of wheat flour LAB (mg/g) after 24h, 48h and $72 \mathrm{~h}$.

680 Fig. 4 Proteolytic (grey) and amylolytic (black) activities of wheat flour LAB.

681 Fig. 5 Antioxidant activity (\%) of wheat flour LAB.

682 Fig. 6 Exopolysaccharide production $(\mathrm{g} / \mathrm{L})$ of wheat flour LAB.

683 Fig. 7 Antifungal inhibition (\%) of wheat flour LAB against Aspergillus niger and Penicillium expansum.

684

685

686

687

688

689

690

691

692

693

694

695

696

697

698

699

700

701

702

703

704

705

706

707

708

709

710

711

712

713

714 


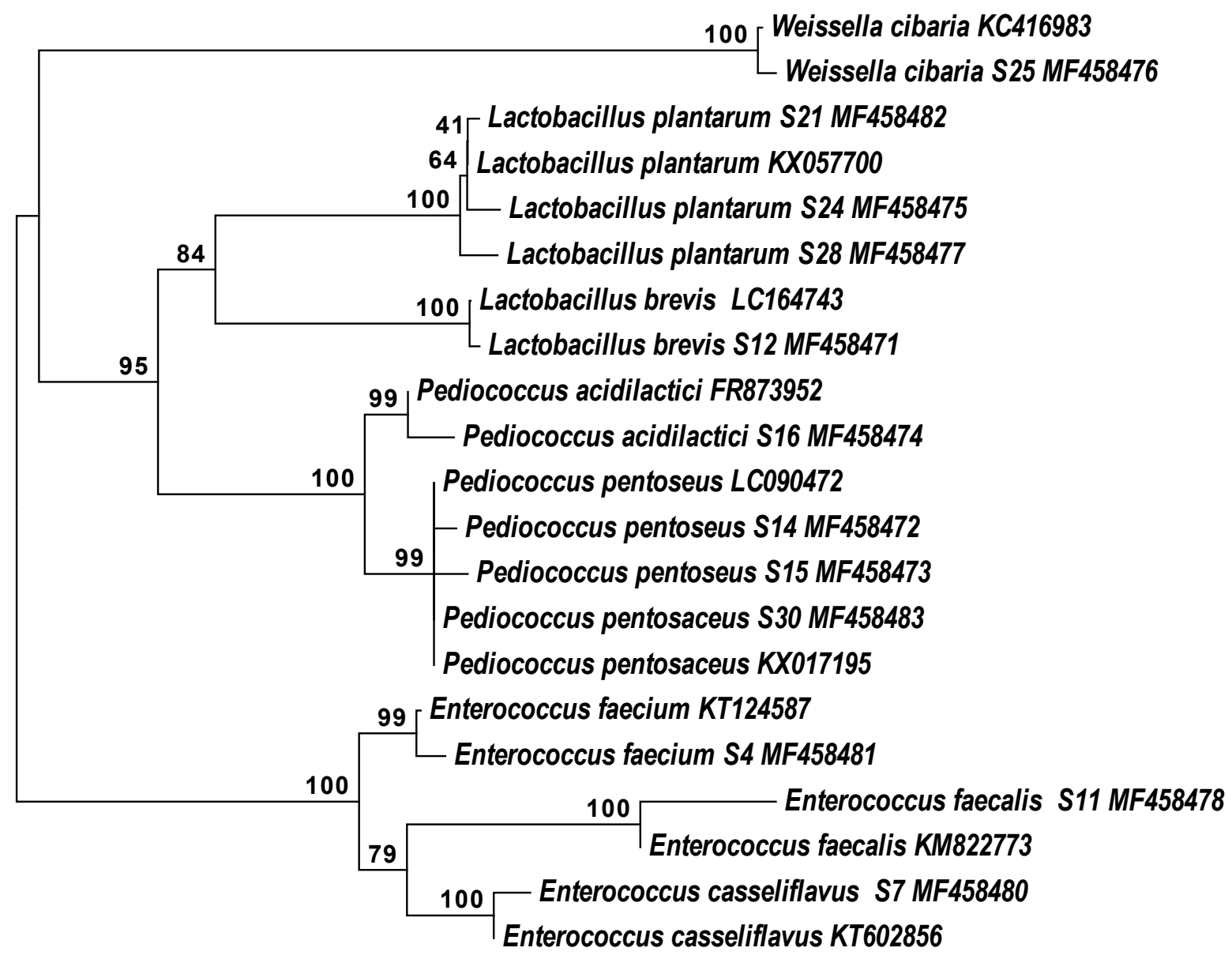


Fig. 2

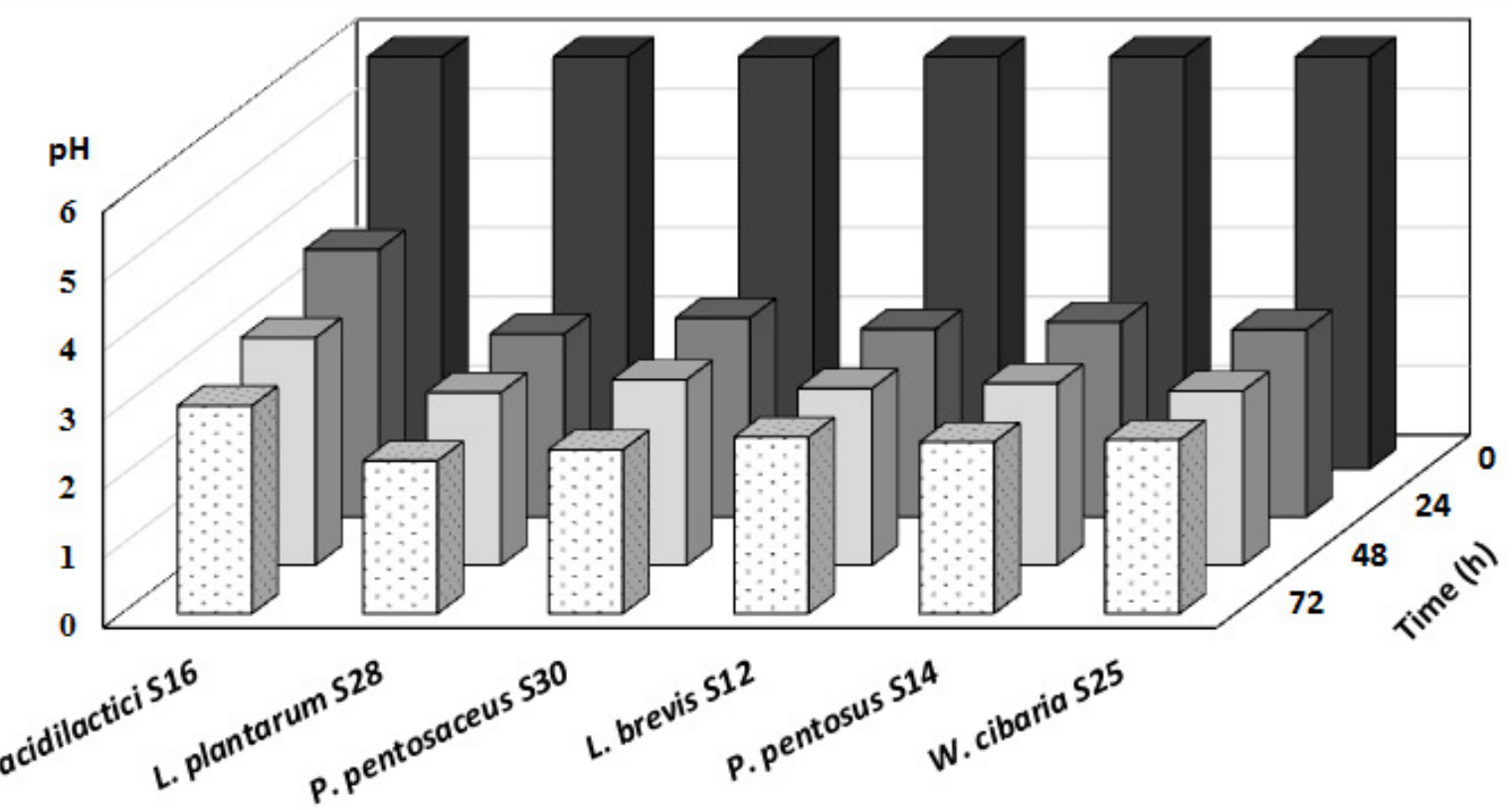

743

744

745

746

747

748

749

750

751

752

753

754

755

756

757

758

759

760

761

762

763

764

765

766

767

768

769

770

771 
Fig. 3

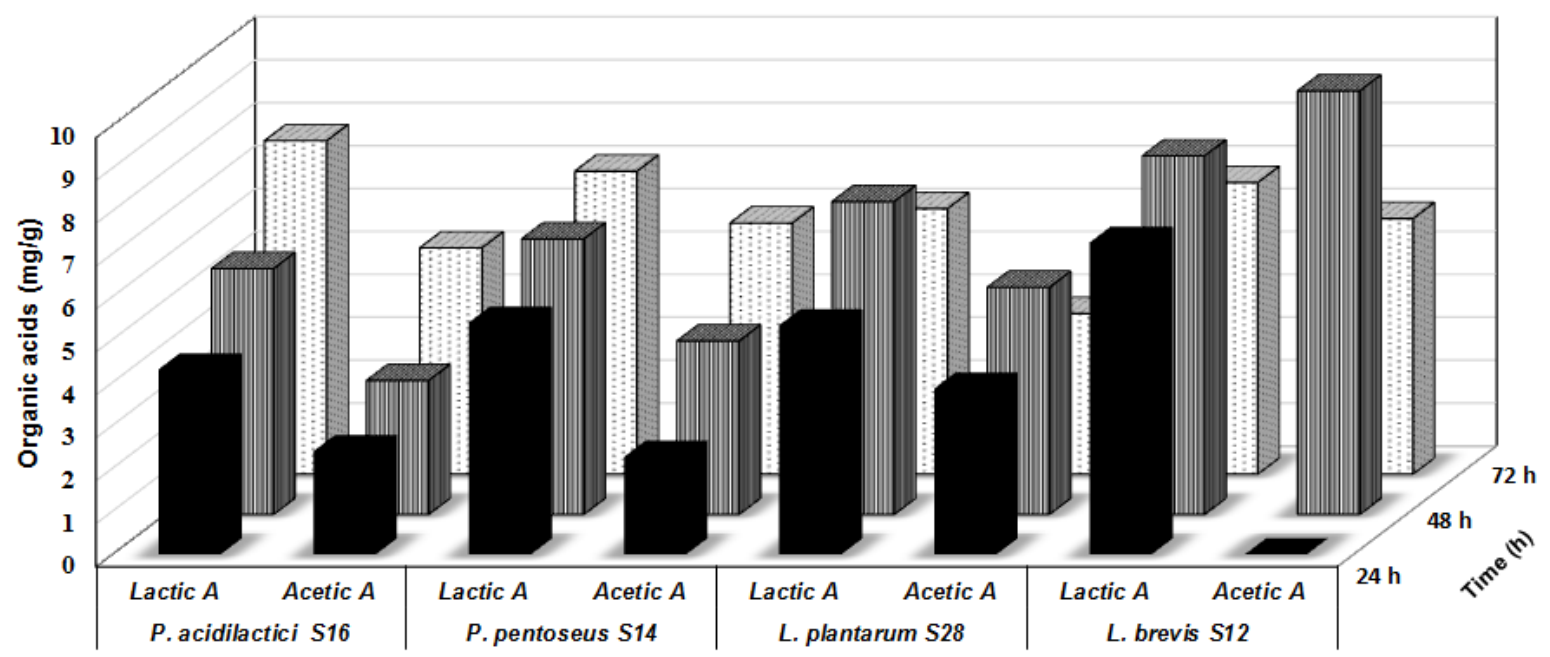


800 Fig. 4

801

802

803

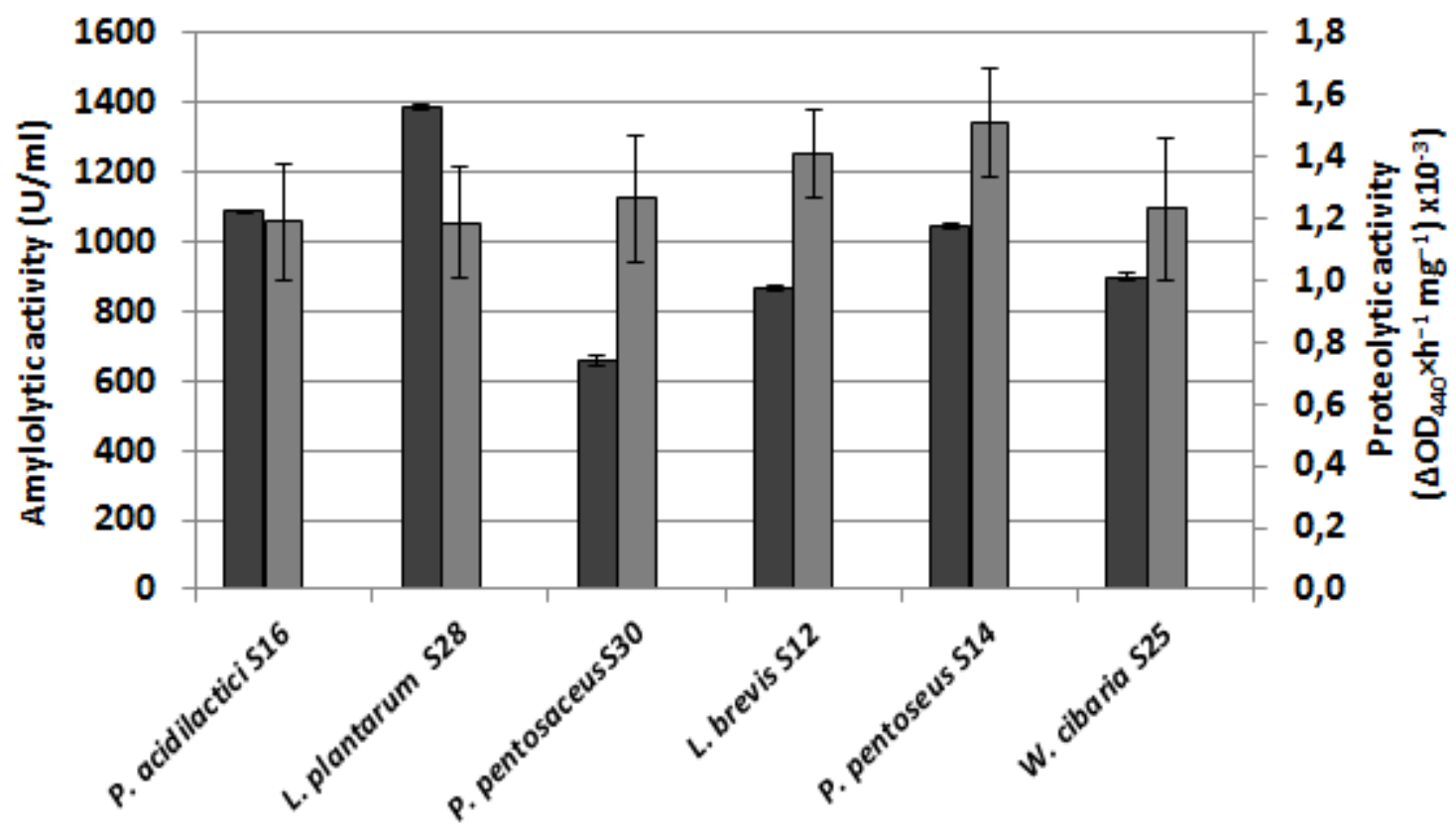

804

805

806

807

808

809

810

811

812

813

814

815

816

817

818

819

820

821

822 
823

824

825

826

827

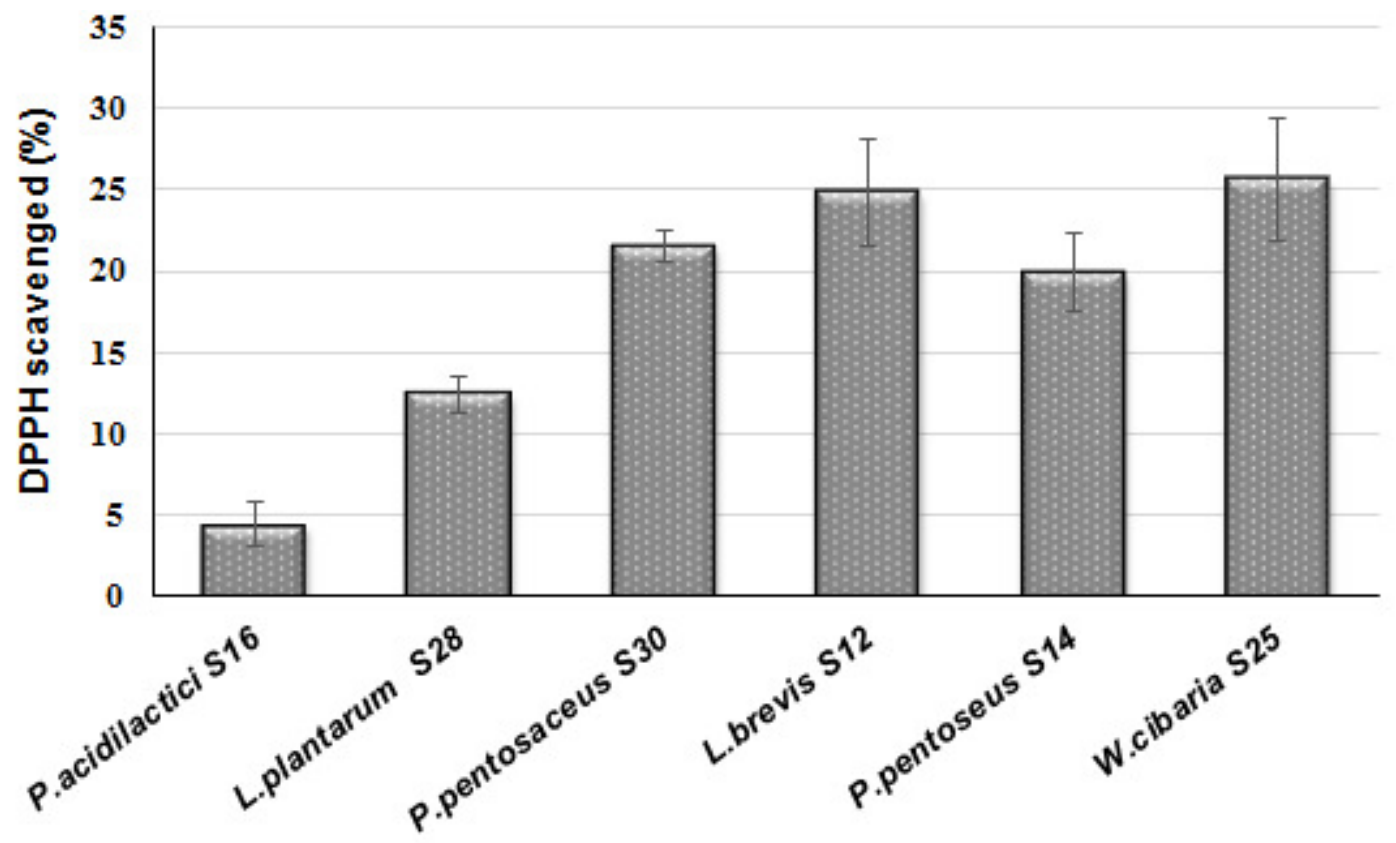

828

829

830

831

832

833

834

835

836

837

838

839

840

841

842

843

844

845 


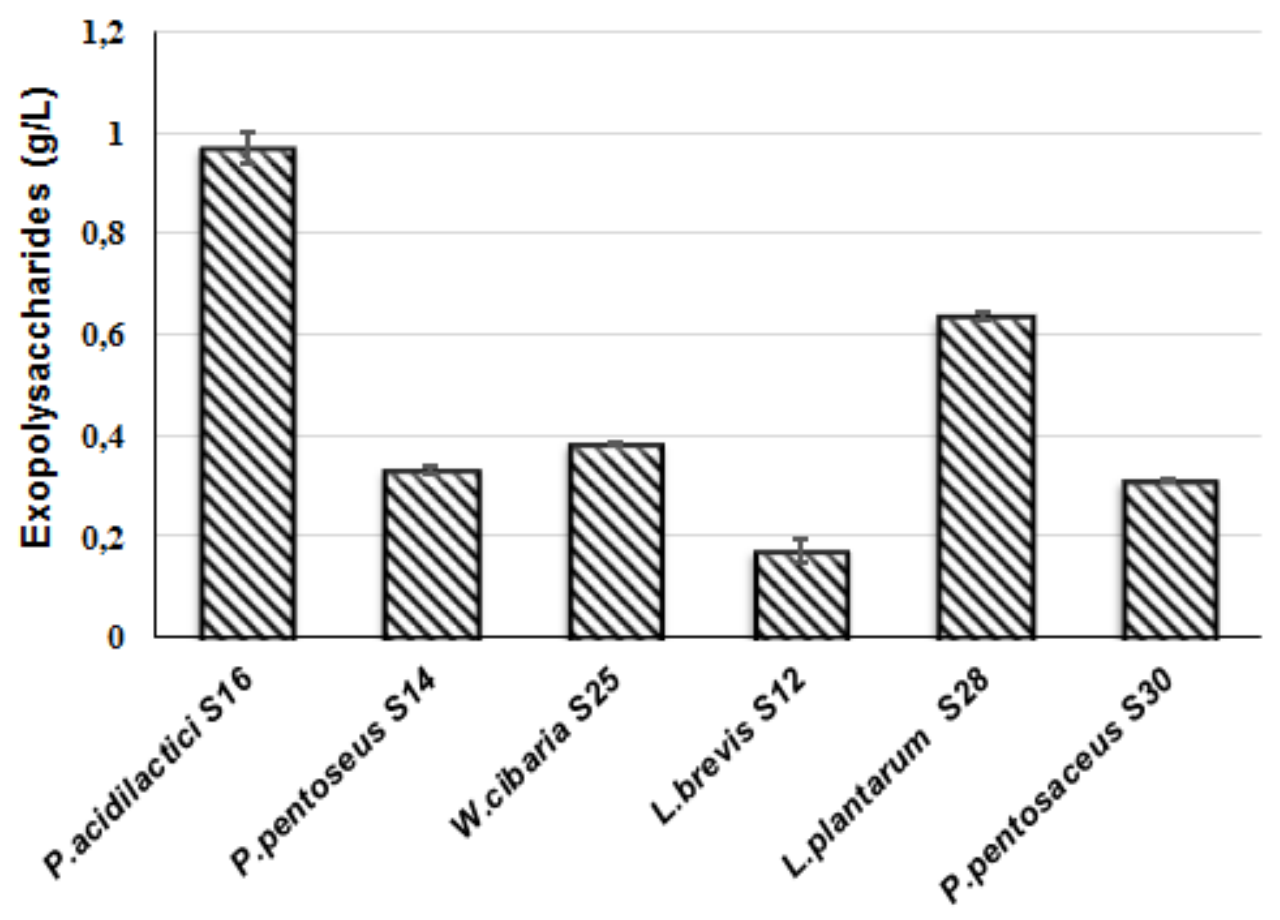

849

850

851

852

853

854

855

856

857

858

859

860

861

862

863

864

865

866

867 
868

Fig. 7

869

870

871

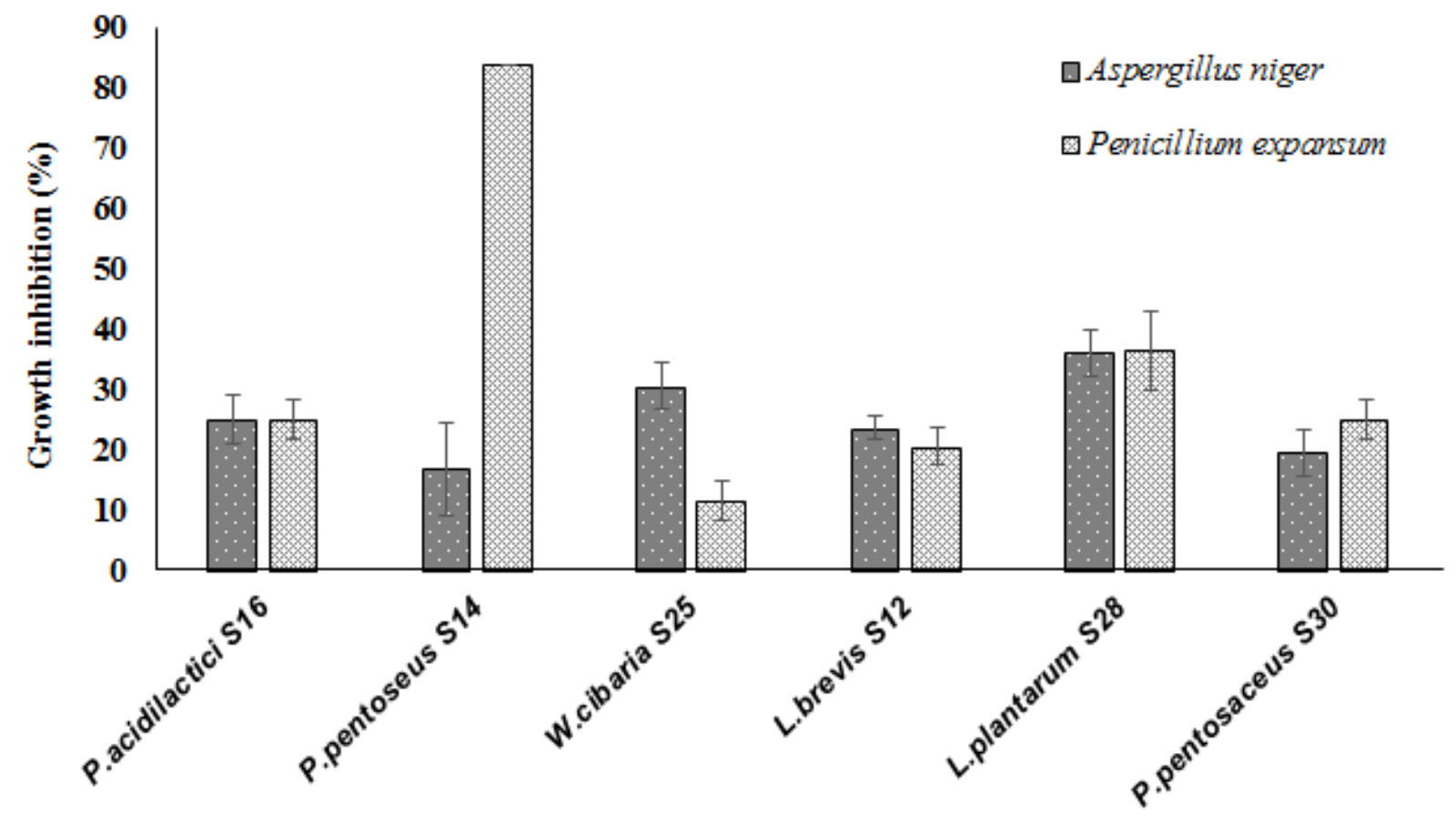

872

873

874

875

876

877

878

879

880

881

882

883

884

885

886

887

888 